\title{
Albedo and Thermal Ecology of White, Red, and Black Cows (Bos taurus) in a Cold Rangeland Environment
}

\author{
John Derek Scasta
}

check for updates

Citation: Scasta, J.D. Albedo and Thermal Ecology of White, Red, and Black Cows (Bos taurus) in a Cold Rangeland Environment. Animals 2021, 11, 1186. https://doi.org/ $10.3390 /$ ani11051186

Academic Editors: Angela Lees, Gene Wijffels and John Gaughan

Received: 22 February 2021

Accepted: 19 April 2021

Published: 21 April 2021

Publisher's Note: MDPI stays neutral with regard to jurisdictional claims in published maps and institutional affiliations.

Copyright: (C) 2021 by the author. Licensee MDPI, Basel, Switzerland. This article is an open access article distributed under the terms and conditions of the Creative Commons Attribution (CC BY) license (https:/ / creativecommons.org/licenses/by/ $4.0 /)$.
Department of Ecosystem Science, University of Wyoming, Laramie, WY 82071, USA; jscasta@uwyo.edu; Tel.: +1-(307)-766-2337

Simple Summary: There is a trend of more black hided beef cattle globally, yet cattle on rangelands have limited thermoregulation options. I measured the winter albedo of cows in fresh snow with pixel analysis ( $n=3$ images) and then external cattle temperatures (Temp $\left.p_{\text {cow }}\right)$, and the differences $(\Delta \mathrm{T})$ between Temp $p_{\text {cow }}$ and ambient air temperature $\left(\right.$ Temp $_{\text {amb }}$ ) of 638 Temp $_{\text {cow }} \times$ Temp amb combinations for white $(n=183)$, red $(n=158)$, and black $(n=297)$ Bos taurus females. Cattle were free roaming extensive Wyoming, USA rangelands along a broad thermal gradient $\left(\approx-33^{\circ} \mathrm{C}\right.$ to $\left.+33^{\circ} \mathrm{C}\right)$ from 2016 to 2018. Albedo differed for white, red, and black cows $\left(0.69,0.16\right.$, and 0.04 , respectively). Temp $p_{\text {cow }}$ was explained by Temp $\mathrm{pmb}_{\mathrm{am}}$, clear sky insolation index, and cow albedo. However, $\Delta \mathrm{T}$ was explained by Temp $p_{a m b}$, long-wave infrared radiation, Temp $p_{c o w}$, and cow albedo. Temp $p_{c o w}$ suggests red and black cows experience $\sim 2 \times$ higher values than white cows at the coldest temperatures.

Abstract: Cattle in high-elevation rangelands experience cold and hot extremes. Given the increase in black hided cattle globally, thermoregulation options on rangelands, and hide color function affecting mammal thermal ecology, this study quantified winter albedo, external cattle temperatures (Temp $\left.\mathrm{p}_{\mathrm{cow}}\right)$, and differences $(\Delta \mathrm{T})$ between Temp $\mathrm{p}_{\mathrm{cow}}$ and ambient air temperature $\left(\mathrm{Temp} \mathrm{p}_{\mathrm{amb}}\right)$, for different color cattle along a thermal gradient $\left(\approx-33{ }^{\circ} \mathrm{C}\right.$ to $\left.+33^{\circ} \mathrm{C}\right)$. From 2016 to 2018 , I measured 638 individual Temp $\mathrm{cow}_{\mathrm{cow}} \times \mathrm{Temp}_{\mathrm{amb}}$ combinations for white $(n=183)$, red $(n=158)$, and black $(n=297)$ Bos taurus female cattle free roaming extensive Wyoming, USA rangelands. Pixel brightness of cow images relative to snow indicated mean ( \pm standard error) albedo for white, red, and black cows $\left(n=3\right.$ of each) was $0.69( \pm 0.15), 0.16( \pm 0.04)$, and $0.04( \pm 0.01)$, respectively $(p=0.0027)$. Temp $p_{\text {cow }}$

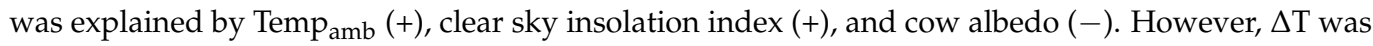
explained by Temp $\mathrm{amb}(-)$, long-wave radiation (infrared; $\left.\operatorname{Rad}_{\mathrm{LW}}(-)\right)$, Temp $\mathrm{P}_{\mathrm{cow}}(+)$, and cow albedo

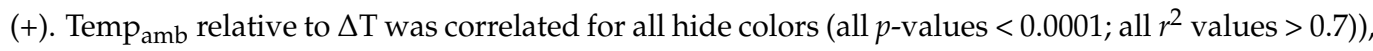
yet slopes $(m)$ were $\sim 2 \times$ greater for red and black cows than white cows.

Keywords: cold stress; convection; $\Delta \mathrm{T}$; heat stress; homoeothermic; solar radiation

\section{Introduction}

Thermal stress on livestock has implications for animal performance, animal welfare, and in extreme cases, even animal survival. Such stressful thermal situations can occur at both the warm and cold ends of the thermal gradient. Given recent climate change and warming trends globally [1], much attention has been given to heat stress and the well documented effects of heat stress on livestock, which include reduced feed intake, reduced performance, and death in extreme cases [2,3]. Given the forecasted rise in global temperature, much of the research has been appropriately focused on heat stress; however, cold stress can be equally problematic as it affects a large proportion of global livestock production regions at discrete periods of the year and induces hormonal and adaptive changes [4]. In North America alone, nearly 2/3 of all livestock inhabit regions with subzero mean temperatures in the winter season (below $0{ }^{\circ} \mathrm{C}$; [4]).

As temperatures decrease and cold stress escalates, animal physiology acclimates to adapt to the lower temperatures with consequences for animal function and production. 
When external temperatures reach a critically low threshold for livestock, animals move out of the zone of thermoneutrality and into a cold thermogenesis stage where metabolism adapts to generate body heat as a coping mechanism (i.e., elevated basal metabolic intensity) [5]. The consequence of this metabolic cold adaptation is an increase in feed requirements ranging from 30 to $70 \%$ in beef cattle [6]. Given the seasonal variation of hot and cold conditions, maintenance energy requirements of cattle also fluctuate drastically in northern latitudes and/or high altitudes during periods of forage deficiencies with realized reductions in animal performance as determined by feed-to-gain ratios [4]. These animal issues are largely a product of the environment that animals inhabit and the associated climatic patterns.

Consequently, environments that experience large thermal gradients across seasons and extreme events present challenging livestock production environments. Environments such as cold steppe high-elevation rangelands often occur near the interface of plains and mountains, in mountainous regions, or in arid deserts and may experience drastic diurnal and seasonal temperature variation. Experimental approaches to understand how animals adapt to such variable thermal environments have included experimental approaches where animals were exposed to cold $\left(3{ }^{\circ} \mathrm{C}\right)$, thermoneutral $\left(25^{\circ} \mathrm{C}\right)$, or hot $\left(35^{\circ} \mathrm{C}\right)$ conditions in artificially housed environments [7], or where animals were confined with limited ability to use the landscape in order to optimally thermoregulate [2].

Thermoregulation is fundamental to physiological and distributional adaptations of thermal conditions for all organisms. Mammals, such as cattle, are homeothermic due to their constant body temperature that is regulated relative to the ambient environmental temperature. Relatedly, the surface temperature of the mammal has an important role in radiative balance and energy loss. It is therefore imperative to understand the difference between the surface temperature of an organism and the temperature of the surrounding environment [8] which is affected by the interface with phenotypic traits such as hide color. Calculation of the difference between the surface temperature of an organism and the temperature of the surrounding environment $(\Delta \mathrm{T})$ is fundamental to animal thermal ecology because $\Delta \mathrm{T}$ is necessary to calculate forced convection, which is heat transfer between an organism and its environment (Equation (1); [8]),

$$
\text { Forced convection }(\mathrm{Q})=\mathrm{h}_{\mathrm{c}} \mathrm{A} \Delta \mathrm{T}
$$

where $h_{c}$ is the surface heat transfer coefficient and $A$ is the surface area of the body of interest. Here, the critical role of an organism's boundary layer thickness and wind speed is accounted for in the calculation of $h_{c}$ (Equation (2); [8]),

$$
\text { Surface heat transfer coefficient }\left(\mathrm{h}_{\mathrm{c}}\right)=\mathrm{f}\left(\mathrm{V}^{\mathrm{k}}{ }_{1} / \mathrm{D}^{\mathrm{k}}{ }_{2}\right)
$$

where $h_{c}$ is a function of both the dimension of the organism, D, and wind speed, $V$, where the exponents $\mathrm{k}$ represent combinations of thermal conductivity, thermal capacity, and thermal expansion coefficients (for which experimental determination for an organism is noted to be technically demanding and not often performed [8]). Similarly, $\Delta \mathrm{T}$ is also important for calculating net radiation $\left(\mathrm{Q}_{\mathrm{n}}\right)$, which is the difference between radiation emitted and radiation received, considered as net loss of energy as heat (Equation (3); [8]),

$$
\text { Net radiation }\left(\mathrm{Q}_{\mathrm{n}}\right)=\mathrm{A} \varepsilon \sigma\left(\mathrm{T}_{\mathrm{o}}{ }^{4}-\mathrm{T}_{\mathrm{e}}{ }^{4}\right)
$$

where $\varepsilon$ is emissivity, $\sigma$ is the Stefan-Boltzmann constant, $T_{0}$ is the organism's temperature, and $T_{e}$ is the environmental temperature.

However, thermal stress of animals is not simply a function of the ambient temperature, but also the interaction with solar radiation, a consideration that was largely neglected in early efforts to develop guidelines for minimizing thermal stress during the transportation phase of livestock production systems [3]. This radiant energy emitted by the sun can vary due to a range of environmental conditions such as cloudiness [9] and approximately half 
is within the short-wave portion of the electromagnetic spectrum (i.e., visible) while the remainder is within both the infrared and ultraviolet portions [10].

Surface properties of an organism, in particular phenotypically expressed hide color, influence the proportion of solar radiation that is reflected. Functionally, this is experienced by an organism when darker surfaces feel hotter and lighter surfaces feel cooler-a concept referred to as albedo [9]. Albedo affects the amount of radiant energy absorbed or reflected, and is a unitless measure that ranges from 0 to 1 , where 0 reflects no solar radiation and 1 reflects all of the solar radiation. Albedo is important for remote sensing and energy balance calculations [11]. Generally, black surfaces are closer to 0 because they absorb the majority of the solar radiation (feel hotter) and white surfaces are closer to 1 because they reflect the majority of the solar radiation (feel cooler).

Consequently, animal hide color and albedo have implications for thermal ecology and thermal stress mitigation. From a practical standpoint, thermal stress mitigation attempts to manipulate the heat load balance where reducing heat loss is the aim during cold stress, but reducing heat load and/or increasing heat loss are the aim during heat stress [3]. For extensive systems where reducing heat load is not possible, such as the case for freeroaming animals in rangeland environments, developing basic thermal ecology information to develop more thermal stress-tolerant animals may be the only viable alternative. The other options for reducing thermal stress identified in a decision tree analysis include (1) relocating to a more suitable area, (2) modifying the environment in the same location, (3) changing operations, or (4) stop producing livestock-all of which are impractical for livestock production enterprises generally [3]. Thus, the notion of matching the animal to the environment has been suggested to be a primary strategy for adapting to environmental variation and extremes and understanding the role of animal albedo is a part of that process [12].

Considering albedo and thermal stress-tolerant animals, it is also important to understand trends in livestock selection and national herd composition. In many regions of the world, the proportion of black beef cattle has been increasing and recent reports indicate that $~ 75 \%$ of all US beef cows were black in $2012[13,14]$. Therefore, given the trend towards more black hided cattle in the US domestic beef herd, that high-elevation rangelands can experience both cold and hot thermal extremes, and the limitation of existing research that has primarily examined cattle in artificial thermal environments that negate solar radiation or only examined cattle in confined feeding operations, I sought to quantify the external surface temperatures of cattle, the difference between the surface temperature of an organism and the temperature of the surrounding environment $(\Delta \mathrm{T})$, and albedo estimates for black, red, and white cattle along a broad thermal gradient.

\section{Materials and Methods}

\subsection{Study Site}

The study area is a high-elevation rangeland approximately $2190 \mathrm{~m}$ a.s.l. near Laramie, WY, USA. This region receives $250-360 \mathrm{~cm}$ of precipitation annually and has a mean monthly temperature range from 0.1 to $26.7^{\circ} \mathrm{C}$. The study area is classified as $B S k$ (B-Arid; $S$-Steppe; $k$-cold) according to the Köppen-Geiger climate classification due to it being temperate, continental, with winter snow, and having a broad thermal gradient [15]. This open rangeland environment inherently provides little to no shade due to its short vegetation and thus, animals are fully exposed to solar radiation, which is not uncommon in global rangelands used for livestock grazing [16]. Cows were provided by the University of Wyoming (UW) Beef Unit and consisted of approximately 40 white Charolais, 250 black Angus, and 40 red Angus and/or Hereford. Cows were multiparous, estimated to be 3 to 7 years of age, and were sampled across a range of lactation and gestation stages that occur across winter and summer seasons. Cattle management followed the guidelines stated in the Guide for the Care and Use of Agricultural Animals in Research and Training [17] and the UW Institutional Animal Care and Use Committee (IACUC Protocol \#20170508DS0060-01). 


\subsection{Cow Albedo Calculations and Analysis}

On 6 January 2017, I captured 3 digital images of commingled white, red, and black Bos taurus cows in the snow using an 8-megapixel camera and then used the open-source image analysis software ImageJ to calculate winter albedo values for the different cow colors (Figure 1; [18]). Cows at the time of sampling were in the 2nd trimester of gestation and non-lactating.
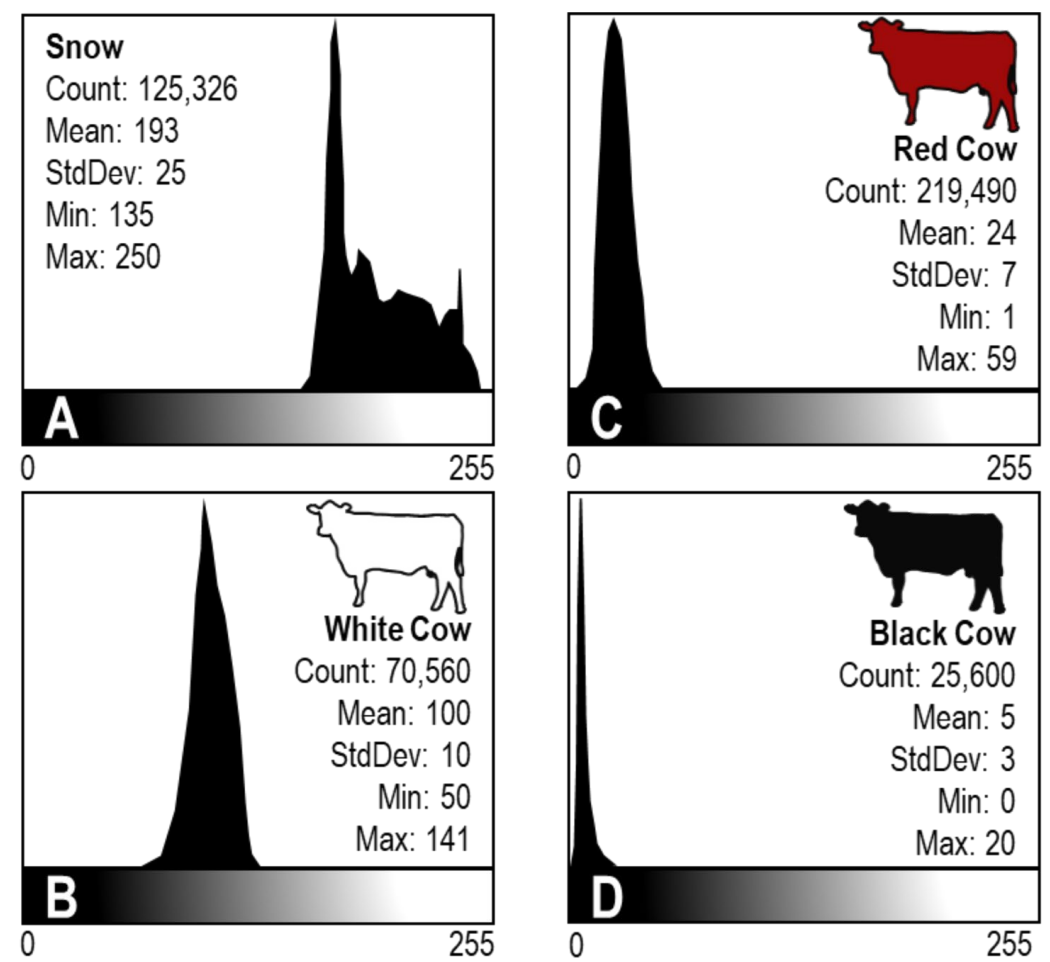

Figure 1. Example of image analysis histograms of frequency of occurrences of different gray pixel values as an indicator of brightness. Each histogram represents pixels selected for (A) snow, (B) a white cow, (C) a red cow, and (D) a black cow, concurrently in a photo. Photos were taken in January 2016 west of Laramie, WY, USA at the University of Wyoming, Agricultural Experiment Station, Laramie Research and Extension Center-Beef Unit and cattle were Bos taurus cows. Analyses were conducted using open-source image analysis software ImageJ.

In each image, snow pixels in the image were analyzed as the reference and considered the baseline constant using a typical snow albedo value of $0.85[19,20]$. For each image, I developed a histogram of the frequency of occurrences of different gray values of selected snow and different colored cow pixels (Figure 1). The mean of these gray value occurrences is an indicator of the brightness of selected pixels which is possible because digital images are produced by a combination of red, green, and blue primary color pixels and each color has a brightness value ranging from 0 to 255 (Figure 1). I used three different images as replicates and then calculated the mean albedo value for snow, and white, red, and black cows within each image [21,22]. For each cow color, I first calculated the relative albedo

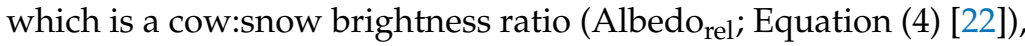

$$
\text { Albedo }_{\text {rel }}=\text { Bright }_{\text {cow }} \div \text { Bright }_{\text {snow }}
$$

where Bright ${ }_{c o w}$ is the mean brightness of specific cow hide pixels (i.e., black, red, or white cows) and Bright ${ }_{\text {snow }}$ is the mean brightness of snow pixels which functions as reference pixels. I then calculated absolute albedo for each cow color (Albedo ${ }_{a b s}$; Equation (5)),

$$
\text { Albedo }_{\mathrm{abs}}=\text { Albedo }_{\text {rel }} \times 0.85
$$


where Albedo $_{\text {rel }}$ is multiplied by the snow albedo reference value of $0.85[11,19,22]$.

Albedo values range from 0 to 1 and were therefore transformed with an arcsine transformation. Data were assessed for normality with a Shapiro-Wilk test and W-statistics and $p$-values indicated a deviation from normality. Thus, I then used a non-parametric KruskalWallis test with hide color as a fixed effect. Finally, with defined alternative hypotheses (HA) for multiple paired comparisons (specifically, HA1: white cow albedo $>$ red cow albedo, HA2: red cow albedo > black cow albedo, and HA3: white cow albedo > black cow albedo), I calculated effect sizes using Cohen's $d$ to understand the magnitude of differences.

\subsection{Cow Thermal Measurements and Relating Tempamb to Temp}

From 2016 to 2018, I measured 638 individual cattle surface temperature $\times$ ambient environmental temperature combinations for the same Bos taurus female cow groups as described above $\left(n_{\text {white }}=183, n_{\text {red }}=158, n_{\text {black }}=297\right)$. At any discrete sampling interval, I was able to collect at least 14 measurements per hide color group. I only used female cattle because change in rectal temperatures of cattle relative to handling may be influenced by sex [23]. This study quantified cattle surface temperature (Temp $\left.p_{\text {cow }}\right)$ and ambient environmental temperature $\left(T e m p_{a m b}\right)$ using two separate thermal instruments simultaneously operated (Figure 2). For Temp $\mathrm{pow}_{\mathrm{co}}$, I used an infrared (IR) high temperature thermometer (Extech Instruments ${ }^{\circledR} 42,545$ made by FLIR Systems ${ }^{\circledR}$, Wilsonville, OR, USA) sensor with a temperature range of -50 to $1000{ }^{\circ} \mathrm{C}$, a distance to target ratio of 50:1, and 0.93 emissivity setting (base setting). The sensor was placed approximately at the top of the shoulder from a distance of 5 to $15 \mathrm{~m}$ and sensed temperature was recorded. For Temp $\mathrm{amb}_{\mathrm{a}}$, I used a handheld weather meter (Kestrel ${ }^{\circledR} 3000$, Boothwyn, PA, USA) that was in the same physical position as the IR sensor and recorded Temp $\mathrm{amb}_{\mathrm{at}}$ at the same approximate time as Temp $p_{\text {cow }}$ (Figure 3). All temperatures were measured in degrees Fahrenheit and converted to degrees Celsius (Figure 3). I then calculated the absolute difference $(\Delta \mathrm{T})$ between Temp $p_{\text {cow }}$ and Tempamb.

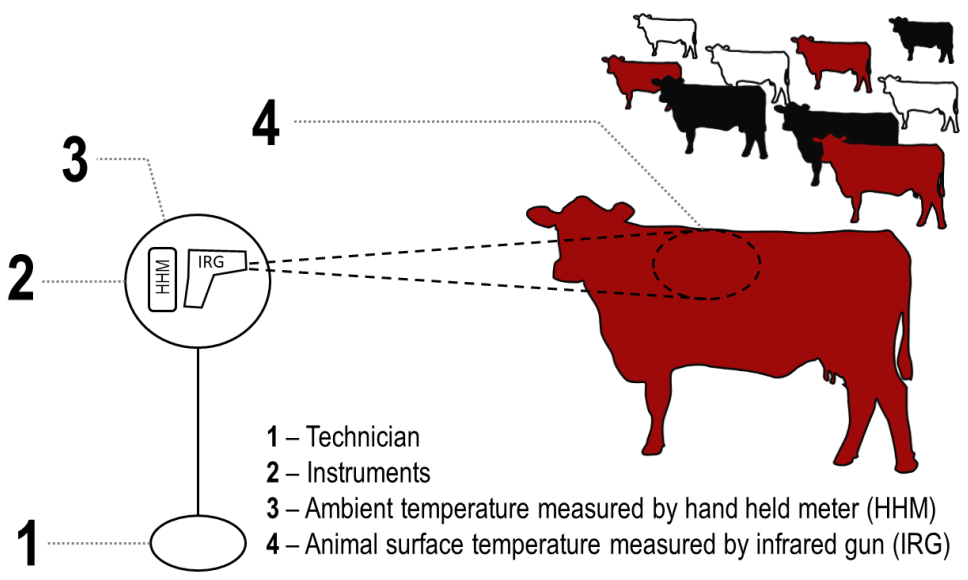

Figure 2. Field method for in situ measurement of ambient environmental temperature (Temp $\mathrm{amb}_{\mathrm{am}}$ ) and cattle surface temperature (Temp $\mathrm{p}_{\mathrm{cow}}$ ) using two separate thermal instruments simultaneously operated by a single technician. Temp $\mathrm{amb}_{\mathrm{a}}$ measured with a handheld meter (HHM; Kestrel $\left.{ }^{\circledR} 3000\right)$. Temp $_{\text {cow }}$ measured with an infrared gun (IRG) high temperature thermometer (Extech Instruments ${ }^{\circledR}$ 42,545 made by FLIR Systems ${ }^{\circledR}$ ) with the laser placed approximately at the top of the shoulder from a distance of 5 to $15 \mathrm{~m}$ and sensed temperature was recorded. Temp $\mathrm{pamb}_{\mathrm{and}}$ and $\mathrm{p}_{\mathrm{cow}}$ were recorded simultaneously with HHM and IRG instruments in the same physical position. Cattle were white, red, and black Bos taurus cows free roaming on rangeland west of Laramie, WY, USA at the University of Wyoming, Agricultural Experiment Station, Laramie Research and Extension Center-Beef Unit. 


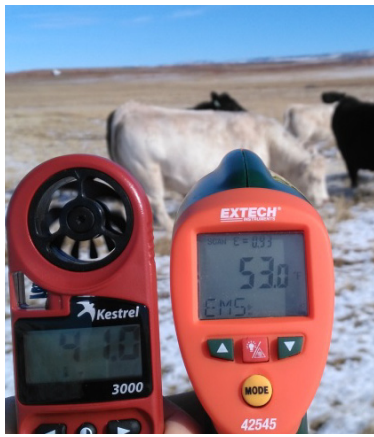

(a) White cow

$\mathrm{Temp}_{\text {cow }}=53^{\circ} \mathrm{F}\left(11.7^{\circ} \mathrm{C}\right)$

Tempamb $=41^{\circ} \mathrm{F}\left(5^{\circ} \mathrm{C}\right)$

$\Delta \mathrm{T}=12^{\circ} \mathrm{F}\left(6.7^{\circ} \mathrm{C}\right)$

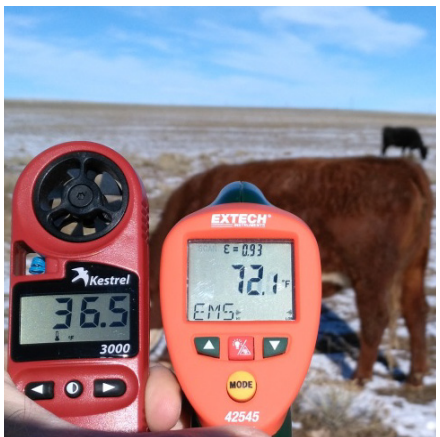

(b) Red cow

$\mathrm{Temp}_{\text {cow }}=72.1^{\circ} \mathrm{F}\left(22.3^{\circ} \mathrm{C}\right)$

Tempamb $=36.5^{\circ} \mathrm{F}\left(2.5^{\circ} \mathrm{C}\right)$

$\Delta \mathrm{T}=35.6^{\circ} \mathrm{F}\left(19.8^{\circ} \mathrm{C}\right)$

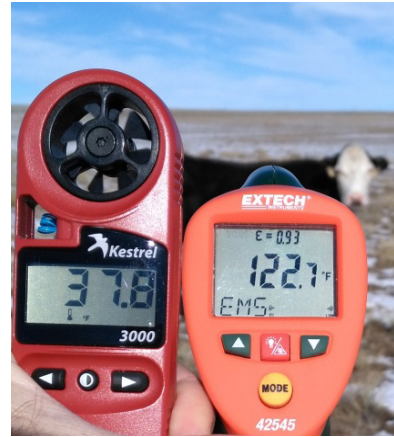

(c) Black cow

Temp cow $=122.7^{\circ} \mathrm{F}\left(50.4^{\circ} \mathrm{C}\right)$

$\mathrm{T}_{\mathrm{amb}}=37.8^{\circ} \mathrm{F}\left(3.2^{\circ} \mathrm{C}\right)$

$\Delta \mathrm{T}=84.9^{\circ} \mathrm{F}\left(47.2^{\circ} \mathrm{C}\right)$

Figure 3. Examples of in situ measurement of ambient environmental temperature (Temp $\mathrm{amb}_{\mathrm{am}}$ ) and cattle surface temperature $\left(\right.$ Temp $\left._{\text {cow }}\right)$ using a handheld meter (HHM; Kestrel $\left.{ }^{\circledR} 3000\right)$ and an infrared gun (IRG) high temperature thermometer (Extech Instruments ${ }^{\circledR} 42,545$ made by FLIR Systems ${ }^{\circledR}$ ). Temperatures collected from animals and the environment in situ were then used to calculate the difference $(\Delta T)$ between Temp $p_{c o w}$ and Temp $p_{a m b}$. Cattle were white, red, and black Bos taurus cows free roaming on rangeland west of Laramie, WY, USA at the University of Wyoming, Agriculture Experiment Station, Laramie Research and Extension Center-Beef Unit.

\subsection{Weather and Solar Radiation Data}

In addition to the in situ derived data described above for cow albedo, Temp cow $_{\text {, and }}$ Temp $\mathrm{amb}_{\mathrm{a}}$ I acquired additional weather and solar radiation data from remotely sensed and publicly available sources based on a priori justification for inclusion in cow thermal ecology modeling as described in greater detail in Table 1. First, I acquired local weather data from the station located at the Laramie Regional Airport west of Laramie, WY, USA, which borders the research ranch, for daily average humidity, wind speed, and dewpoint temperature. Second, I acquired daily maximum vapor pressure deficit (VPD) estimates from the Parameter-elevation Relationships on Independent Slopes Model (PRISM) interpolation method that extrapolates data based on a digital elevation model (DEM) at a resolution of 2.5 arcmin ( 4-km). PRISM data are derived from some 10,000 stations weighted relative to physiographic similarity to a grid cell of interest [24,25]. I used the cell at latitude 41.2990 and longitude -105.6540 with data from the AN81d dataset. Third, I used the same coordinates for the PRISM data to acquire daily solar radiation data from National Aeronautics and Space Administration (NASA) satellites through the Prediction Of Worldwide Energy Resources (POWER) project for earth skin temperature (Temp earth), clear sky insolation index (KTclear), long-wave radiation (infrared; $\operatorname{Rad}_{\mathrm{LW}}$ ), and short-wave radiation (visible; $\operatorname{Rad}_{\text {SW }}$ ) which is produced natively on a global $1^{\circ} \times 1^{\circ}$ latitude/longitude grid and then remapped to a $0.5^{\circ} \times 0.5^{\circ}$ latitude/longitude grid scale via bilinear interpolation and/or replication [26]. 
Table 1. Potential predictor variables and associated justification for inclusion for modeling external surface temperatures of red, white, and black hided cattle (Temp $\left.p_{c o w}\right)$ and then the difference $(\Delta \mathrm{T})$ between Temp $\mathrm{p}_{\mathrm{cow}}$ and the ambient temperature of the surrounding environment (Temp $\mathrm{pmb}_{\mathrm{amb}}$ ). Variables are listed in alphabetical order. Cattle were white, red, and black Bos taurus cows free roaming on rangeland west of Laramie, WY, USA at the University of Wyoming, Agriculture Experiment Station-Beef Unit.

\begin{tabular}{|c|c|}
\hline Variable & Biological Rationale and Justification for Inclusion in Modeling \\
\hline $\begin{array}{l}\text { Ambient environmental temperature } \\
\qquad\left(\text { Temp } \mathrm{p}_{\mathrm{amb}}\right)^{\mathrm{a}}\end{array}$ & $\begin{array}{l}\text { Also noted as air temperature, this is important to determine an organism's deviation } \\
\text { from the zone of thermoneutrality and influences convection coefficients [27]. }\end{array}$ \\
\hline Clear sky insolation index (KTClear) ${ }^{\mathrm{d}}$ & $\begin{array}{l}\text { Used for the weather prediction of intra-day solar forecasting [28] and for daylight } \\
\text { utilization in farm animal production [29]. Fraction of insolation available at the top of } \\
\text { the atmosphere and an indication of the total solar radiation incident on a horizontal } \\
\text { earth surface. }\end{array}$ \\
\hline Cow winter albedo ${ }^{1, a}$ & $\begin{array}{l}\text { Commonly used in remote sensing research, this refers to the proportion of solar } \\
\text { radiation reflected by any surface (water, land, organismal), where darker surfaces } \\
\text { reflect less than lighter surfaces and is important for determining energy balance [30]. }\end{array}$ \\
\hline Cow surface temperature $\left(\text { Temp }_{\text {cow }}\right)^{a}$ & $\begin{array}{l}\text { Measured in winter when snow was available to relativize pixel brightness in images. } \\
\text { The surface temperature of an organism can be used to predict convective heat } \\
\text { loss [27]. }\end{array}$ \\
\hline Dewpoint temperature $\left(\text { Temp }_{\text {dew }}\right)^{c}$ & $\begin{array}{c}\text { The temperature to which air must be cooled, relative to pressure and water-vapor } \\
\text { content, in order to reach saturation and for dew or condensation to form; this } \\
\text { influences evaporative heat loss [31]. }\end{array}$ \\
\hline Earth skin temperature $\left(\text { Temp } p_{\text {earth }}\right)^{d}$ & $\begin{array}{l}\text { The earth's surface temperature as opposed to the meteorological definition of surface } \\
\text { temperature which is actually measured by suspended air thermometers above the } \\
\text { surface of the earth; this reflects the thermal environments of physiologically diverse } \\
\text { organisms [32]. }\end{array}$ \\
\hline Humidity ${ }^{b}$ & $\begin{array}{l}\text { The amount of water vapor that is in the atmosphere; humidity interacts with } \\
\text { temperature and influences thermal stress of animals [33]. Humidity is also important } \\
\text { given the temperature-humidity index (THI) which can have a combined interactive } \\
\text { impact [3]. }\end{array}$ \\
\hline Long-wave radiation (infrared; $\operatorname{Rad}_{\mathrm{LW}}{ }^{\mathrm{d}}$ & $\begin{array}{l}\text { Downward thermal infrared long-wave radiative flux }{ }^{\mathrm{d}} \text {; has an important role in } \\
\text { predicting radiative heat gain for animals with different hide colors, particularly at the } \\
\text { surface of the animal [34]; may govern simulated temperatures of wildlife species [35]. }\end{array}$ \\
\hline Short-wave radiation (visible; $\left.\operatorname{Rad}_{\mathrm{SW}}\right)^{\mathrm{d}}$ & $\begin{array}{l}\mathrm{d} \text { All sky insolation incident on a horizontal surface (short-wave) }{ }^{\mathrm{d}} \text {; short-wave solar } \\
\text { radiation has been used to develop a thermal stress index for dairy cows in Brazil [9]. }\end{array}$ \\
\hline Vapor pressure deficit (VPD) ${ }^{\mathrm{c}}$ & $\begin{array}{l}\text { The difference between the amount of moisture in the air and the maximum moisture } \\
\text { the air can hold at saturation; this affects the exchange of the energy between an } \\
\text { animal and its environment through an interaction with temperature [36,37]. }\end{array}$ \\
\hline Wind speed ${ }^{\mathrm{b}}$ & $\begin{array}{l}\text { Also noted as wind flow speed, this is a basic atmospheric measurement of air moving } \\
\text { from high to low pressure often driven by temperature flux. This variable is } \\
\text { considered in the calculation of the convection coefficient and an influential for } \\
\text { predicting the surface temperature of an organism [36]. }\end{array}$ \\
\hline
\end{tabular}

\footnotetext{
${ }^{1}$ Determined through analysis of digital pixels with cows in fresh snow and relativized with published snow albedo values; ${ }^{\text {a-d }}$ Data Source $\left({ }^{\mathrm{a}}\right.$ Field Measurement, ${ }^{\mathrm{b}}$ Laramie Airport Weather Station, ${ }^{\mathrm{c}}$ PRISM [25], ${ }^{\mathrm{d}}$ NASA [26]).
}

\subsection{Temp cow $_{\text {and }} \Delta T$ Modeling}

I conducted a model selection analysis using Akaike's information criterion corrected for small sample (AICc) sizes first for Temp $p_{\text {cow }}$ and then separately for $\Delta \mathrm{T}$ using the AICcmodavg package in R [38,39]. Prior to modeling, I first assessed correlation coefficients for explanatory variables acquired from similar sources (in situ animal or environmental measurement, local weather station measurement, PRISM-extrapolated measurement, or NASA satellite-derived measurement) to exclude similarly sourced autocorrelated explanatory variables from final models using a cutoff of $r>0.7[40,41]$. Consequently, Temp earth was highly correlated with both $\operatorname{Rad}_{\text {LW }}$ and $\operatorname{Rad}_{\text {SW }}$ variables and thus removed, humidity was highly correlated with wind speed and thus removed, and VPD was highly correlated with Temp dew and thus removed.

I then conducted each model selection analysis in categorical steps. Step one was to determine the top "weather" variable and included Temp $\mathrm{pmb}_{\mathrm{am}}$, Temp $\mathrm{p}_{\mathrm{dew}}$, and humidity. 
Step two was to determine the top "solar radiation" variable and included Rad $\operatorname{LW}_{\text {, }} \operatorname{Rad}_{\mathrm{SW}}$, and KTClear. Step three was to then build top candidate models that included the top models from the first modeling steps with the additional incorporation of in situ animal measurements [42]. Null models were included in each step. This approach allows for the identification of the most informative yet most parsimonious model explaining a response variable. At each categorical step, I scaled AICc values to the top model by relativizing the model with the lowest AICc (i.e., the top model in the step) set at zero and then calculating differences between the top model and each of the other models ( $\triangle \mathrm{AICC}$ ) in order to rank models. Models that had $\triangle \mathrm{AIC}$ c scores $\leq 2$ were considered to be in the top set of models. Akaike weights $\left(\omega_{i}\right)$ indicate the relative likelihood of models and were used to determine top models [42]. I then calculated $95 \%$ confidence intervals in a final screening approach to identify uninformative variables in final models [42].

Finally, I also used linear least squares regression to analyze how Temp amb predicts $\Delta \mathrm{T}$ as stratified by cow hide color. Strength of relationships was determined based on the correlation coefficient $\left(r^{2}\right)$ and significant statistical differences based on $\alpha=0.05$. To compare the slopes of the regression lines as stratified by cow hide color, I then used an analysis of covariance (ANCOVA) with Tukey's corrected $p$-value as an indicator of significant differences in a post hoc comparison. Due to unequal variances as indicated by a Levene's test, I also included a Kruskal-Wallis test. Finally, due to missing identification tags and cows being culled/added over time, I was unable to track individual animals and thus, no repeated measures were accounted for in any analyses.

\section{Results}

The pixel analysis histograms revealed different frequency of occurrences of gray values for snow, white cows, red cows, and black cows along the dark to bright gradient (Figure 1A-D). In the example provided from the analyses of one of the images in Figure 1A-D, such differences are apparent. For snow pixels, the mean value was 193 which occurs on the bright end of the scale, with a range from 135 to 250 (Figure 1A). Snow pixels had a standard deviation (SD) of 25 which indicates greater variation than of the cows (white cow $\mathrm{SD}=10$, red cow $\mathrm{SD}=7$, and black cow $\mathrm{SD}=3$ ), which is likely due to shadows or other microspatial features on the surface (Figure 1A-D). Likewise, the low variation for black cows is likely due to a lack of confounding effects from shadows. For white cow pixels, the mean value was 100 which occurs near the middle of the scale, with a range from 50 to 141 (Figure 1B). For red cows, the mean value was 24 which occurs near the dark end of the scale, with a range from 1 to 59 (Figure 1C). For black cows, the mean value was 5 which occurs nearly at the darkest end of the scale with a range from 0 to 20 (Figure 1D).

Cow winter albedo values differed significantly relative to cow hide color $(p$-value $=0.027$; Figure 4). Mean white cow albedo $=0.69( \pm 0.15$ standard error $(\mathrm{SE}))$, mean red cow albedo $=0.16( \pm 0.04 \mathrm{SE})$, and mean black cow albedo $=0.04( \pm 0.1 \mathrm{SE})$ (Figure 4$)$. The effect of the differences was greatest between white and black cows (Cohen's $\mathrm{d}=2.522$ ) and the least between red and black cows (Cohen's $d=1.754$ ) (Figure 4).

For the in situ and satellite-derived measurements, means and ranges are presented in Table 2. Mean Temp amb was $4.4^{\circ} \mathrm{C}$ with a range from -32.8 to $35.6^{\circ} \mathrm{C}$. Mean Temp $\mathrm{cow}_{\text {was }}$ $32.4^{\circ} \mathrm{C}$ with a range from -10.7 to $63.1^{\circ} \mathrm{C}$. $\Delta \mathrm{T}$ mean was $28.0^{\circ} \mathrm{C}$ with a range from -2.2 to $83.3^{\circ} \mathrm{C}$. When stratified by hide color, $\Delta \mathrm{T}$ mean for white cows was $48.7^{\circ} \mathrm{C}$ with a range of $-2.2-48.7^{\circ} \mathrm{C}, \Delta \mathrm{T}$ mean for red cows was $70.8^{\circ} \mathrm{C}$ with a range from -1.8 to $70.8^{\circ} \mathrm{C}$, and $\Delta \mathrm{T}$ mean for black cows was $83.3^{\circ} \mathrm{C}$ with a range from -0.9 to $83.3^{\circ} \mathrm{C}$. Weather data in this study included Temp $\mathrm{pew}_{\text {dew }}$ with a mean of $-10.0^{\circ} \mathrm{C}$ and a range from -27.6 to $7.1^{\circ} \mathrm{C}$, humidity with a mean of $56.7 \%$ and a range from 9.0 to $84.0 \%$, VPD with a mean of $13.5 \mathrm{hPa}$ and a range from 0.6 to $32.5 \mathrm{hPa}$, and wind speed with a mean of $29.0 \mathrm{~km} / \mathrm{h}$ and a range from 11.3 to $53.1 \mathrm{~km} / \mathrm{h}$. Satellite-derived measurements in this study included KTClear with a mean of 0.6 and a range from 0.3 to 0.8 , Tempearth with a mean of $-0.1{ }^{\circ} \mathrm{C}$ and a range from -24.6 to $23.0^{\circ} \mathrm{C}, \operatorname{Rad}_{\mathrm{LW}}$ with a mean of $5.9 \mathrm{~kW}$ hr per $\mathrm{m}^{2}$ per day and a range 
from 3.6 to $8.7 \mathrm{~kW}$ hr per $\mathrm{m}^{2}$ per day, and Radsw with a mean of $3.9 \mathrm{~kW}$ hr per $\mathrm{m}^{2}$ per day and a range from 1.3 to $8.5 \mathrm{~kW} \mathrm{hr}$ per $\mathrm{m}^{2}$ per day.

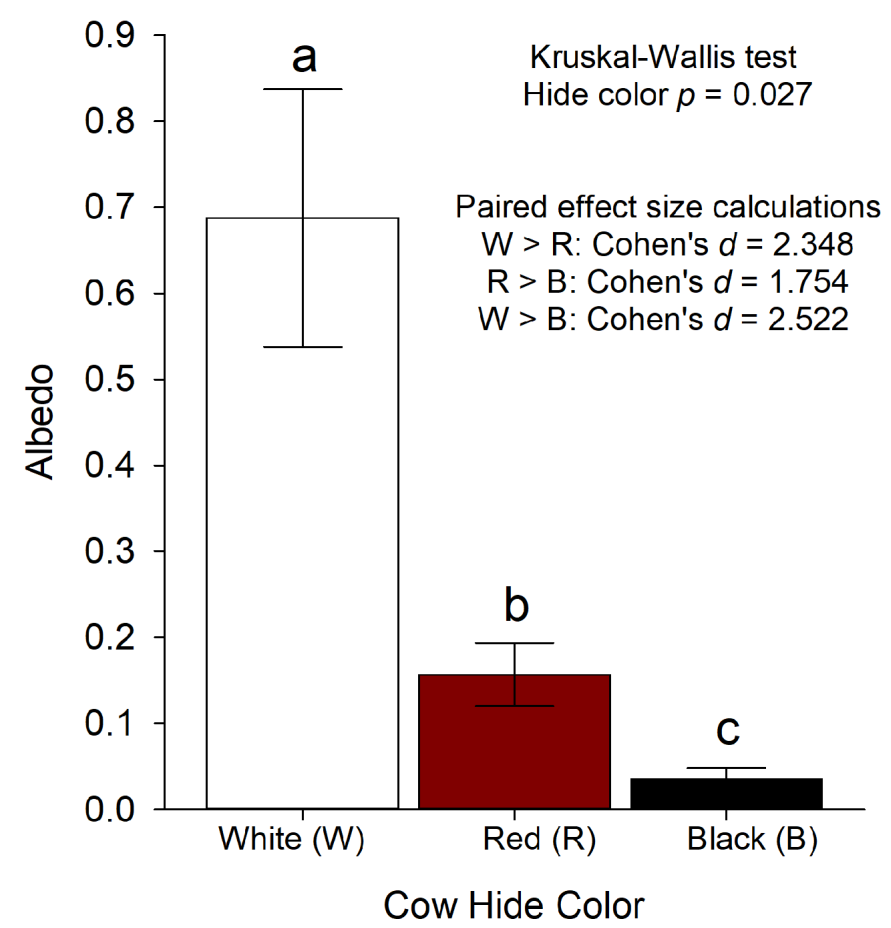

Figure 4. Winter albedo values for white, red, and black cows. Albedo values derived from pixel analyses with snow albedo as a reference. Data were transformed with an arcsine transformation and then analyzed with a non-parametric Kruskal-Wallis test with hide color as the fixed effect. Cohen's $d$ effect sizes were calculated to understand the magnitude of differences based on the defined alternative hypotheses (HA) for each paired comparison; specifically, HA1: white cow albedo > red cow albedo, HA2: red cow albedo > black cow albedo, and HA3: white cow albedo > black cow albedo. Significant statistical differences were based on $\alpha=0.05$ (and indicated by different letters; $(\mathbf{a}-\mathbf{c}))$. Cattle were red, white, and black Bos taurus cows free roaming on rangeland west of Laramie, WY, USA at the University of Wyoming, Agriculture Experiment Station, Laramie Research and Extension Center-Beef Unit.

Table 2. Units, means, minimums, and maximums of potential predictor variables and associated justification for inclusion for modeling external surface temperatures of red, white, and black hided cattle (Temp $\left.\mathrm{p}_{\mathrm{cow}}\right)$ and then the difference $(\Delta \mathrm{T})$ between Temp $\mathrm{p}_{\mathrm{cow}}$ and the ambient temperature of the surrounding environment (Temp $\left.\mathrm{pmb}_{\mathrm{m}}\right)$. Variables are listed in alphabetical order. Cattle were white, red, and black Bos taurus cows free roaming on rangeland west of Laramie, WY, USA at the University of Wyoming, Agriculture Experiment Station, Laramie Research and Extension Center-Beef Unit.

\begin{tabular}{|c|c|c|c|c|}
\hline Variable & Unit & Mean & Minimum & Maximum \\
\hline Ambient environmental temperature $\left(\right.$ Temp $\left._{\mathrm{amb}}\right)$ & ${ }^{\circ} \mathrm{C}$ & 4.4 & -32.8 & 35.6 \\
\hline Clear sky insolation index (KTClear) & unitless index; 0-1 & 0.6 & 0.3 & 0.8 \\
\hline Cow winter albedo & unitless index; 0-255 & 0.25 & 0.04 (black cows) & 0.69 (white cows) \\
\hline Cow surface temperature $\left(\right.$ Temp $\left._{\text {cow }}\right)$ & ${ }^{\circ} \mathrm{C}$ & 32.4 & -10.7 & 63.1 \\
\hline Dewpoint temperature $\left(\right.$ Temp $\left._{\mathrm{dew}}\right)$ & ${ }^{\circ} \mathrm{C}$ & -10.0 & -27.6 & 7.1 \\
\hline Earth skin temperature (Temp $p_{\text {earth }}$ ) & ${ }^{\circ} \mathrm{C}$ & -0.1 & -24.6 & 23.0 \\
\hline Humidity & $\%$ & 56.7 & 9.0 & 84.0 \\
\hline Long-wave radiation (infrared; $\operatorname{Rad}_{\mathrm{LW}}$ ) & $\mathrm{kW}$ hr per $\mathrm{m}^{2}$ per day & 5.9 & 3.6 & 8.7 \\
\hline Short-wave radiation (visible; Radsw) & $\mathrm{kW}$ hr per $\mathrm{m}^{2}$ per day & 3.9 & 1.3 & 8.5 \\
\hline Vapor pressure deficit (VPD maximum) & $\mathrm{hPa}$ & 13.5 & 0.6 & 32.5 \\
\hline Wind speed & $\mathrm{km} / \mathrm{h}$ & 29.0 & 11.3 & 53.1 \\
\hline
\end{tabular}


For the first information theory modeling approach with Temp $p_{\text {cow }}$ as the response variable, the top weather model was Temp $\mathrm{pmb}_{\mathrm{m}}$ and neither $T \mathrm{Tem}_{\mathrm{dew}}$ nor wind speed were competitive (Table 3$)$. Akaike weights $\left(\omega_{i}\right)$ suggest Temp amb was orders of magnitude more informative for Temp $p_{\text {cow }}$ than Temp $p_{\text {dew }}$ or wind speed. The top solar radiation model was KTClear and neither $\mathrm{Rad}_{\mathrm{LW}}$ nor Radsw were competitive (Table 3 ). Akaike weights suggest KTClear was 97 times more informative for Temp $p_{\text {cow }}$ than $\operatorname{Rad}_{\mathrm{LW}}$ or Rad $\mathrm{R}_{\mathrm{SW}}$. The overall top model included Temp $\mathrm{amb}_{\mathrm{a}}$, KTClear, and Albedo and was orders of magnitude more informative for Temp $p_{\text {cow }}$ than any other model. The parameter estimate for Temp $\mathrm{pmb}_{\mathrm{m}}$ was positive indicating that as ambient environmental temperatures increase, so does Temp $\mathrm{p}_{\text {cow }}$. The parameter estimate for KTClear was also positive, indicating that as the proportion of total solar radiation that reaches the surface of the earth increases, so does Temp $p_{\text {cow }}$. The parameter estimate for Albedo was negative, indicating an inverse relationship where lower albedo results in higher Temp $p_{\text {cow }}$. The $95 \%$ confidence intervals for these three parameter estimates all overlap zero and indicate that Temp $\mathrm{amb}_{\mathrm{m}}$, KTClear, and Albedo regulate Temp $\mathrm{p}_{\mathrm{cow}}$ and are informative explanatory variables (Table 4).

Table 3. Weather, radiation, and cow albedo models assessed for cow surface temperature (Temp $\left.\mathrm{p}_{\text {cow }}\right)$ for white, red, and black Bos taurus cows near Laramie, WY, USA.

\begin{tabular}{|c|c|c|c|c|}
\hline Model & $\mathbf{K}$ & AICc & $\Delta \mathrm{AICc}$ & $\omega_{\mathrm{i}}$ \\
\hline \multicolumn{5}{|c|}{ Step 1-Weather Models } \\
\hline Ambient Temperature $\left(\right.$ Temp $\left._{\mathrm{amb}}\right)$ & 3 & 4967.08 & 0.00 & 1 \\
\hline Dewpoint Temperature $\left(\right.$ Temp $\left._{\text {dew }}\right)$ & 3 & 4980.38 & 13.30 & 0 \\
\hline Wind Speed & 3 & 5023.33 & 56.25 & 0 \\
\hline Null & 2 & 5023.93 & 56.85 & 0 \\
\hline \multicolumn{5}{|c|}{ Step 2-Radiation Models } \\
\hline Clear Sky Insolation (KTClear) & 3 & 4988.16 & 0.00 & 0.97 \\
\hline Long-wave Radiation $\left(\operatorname{Rad}_{\mathrm{LW}}\right)$ & 3 & 4995.78 & 7.62 & 0.02 \\
\hline Short-wave Radiation (Radsw) & 3 & 4998.08 & 9.92 & 0.01 \\
\hline Null & 2 & 5023.93 & 35.77 & 0.00 \\
\hline \multicolumn{5}{|c|}{ Step 3-Top Models + Winter Albedo } \\
\hline Temp $\mathrm{amb}+$ KTClear + Albedo & 5 & 4674.57 & 0.00 & 1 \\
\hline Temp $\mathrm{amb}+$ KTClear & 4 & 4959.79 & 285.22 & 0 \\
\hline Temp $\mathrm{amb}_{\mathrm{a}}$ & 3 & 4967.08 & 292.51 & 0 \\
\hline KTClear & 3 & 4988.16 & 313.58 & 0 \\
\hline Null & 2 & 5023.93 & 349.35 & 0 \\
\hline
\end{tabular}

Table 4. Top candidate model parameter estimates and 95\% confidence intervals for cow surface temperature (Temp $\mathrm{p}_{\mathrm{cow}}$ ) for white, red, and black Bos taurus cows near Laramie, WY, USA.

\begin{tabular}{cccc}
\hline Variable & Estimate & Lower & Upper \\
\hline Ambient Temperature (Temp $\mathrm{amb}$ ) & 0.1770 & 0.1328 & 0.2213 \\
Clear Sky Insolation (KTClear) & 19.172 & 13.1404 & 25.2043 \\
Albedo & -27.026 & -29.8800 & -24.1729 \\
\hline
\end{tabular}

For the second information theory modeling approach with $\Delta \mathrm{T}$ as the response variable, the top weather model was Temp $p_{a m b}$ and neither Temp $p_{\text {dew }}$ nor wind speed were competitive (Table 5). Akaike weights suggest Temp $\mathrm{pmb}_{\mathrm{mb}}$ was orders of magnitude more informative for $\Delta \mathrm{T}$ than $T e m p_{\text {dew }}$ or wind speed. The top solar radiation model was $\operatorname{Rad}_{\mathrm{LW}}$ and neither Radsw nor KTClear were competitive (Table 5). Akaike weights suggest $\operatorname{Rad}_{\mathrm{LW}}$ was orders of magnitude more informative for $\Delta \mathrm{T}$ than Radsw or KTClear. The overall top model included Temp $\mathrm{amb}_{\mathrm{mb}}$, $\operatorname{Rad}_{\mathrm{LW}}$, Albedo, and Temp $\mathrm{p}_{\mathrm{cow}}$ and was orders of magnitude more informative for $\Delta \mathrm{T}$ than any other model. The parameter estimate for Temp $\mathrm{amb}_{\mathrm{a}}$ was negative, indicating that as ambient environmental temperatures increase, $\Delta \mathrm{T}$ decreases. The parameter estimate for $\operatorname{Rad}_{\mathrm{LW}}$ was also negative, indicating that as long-wave solar radiation (infrared) increases, $\Delta \mathrm{T}$ decreases. The parameter estimate for Albedo was nega- 
tive, indicating an inverse relationship where lower albedo results in $\Delta \mathrm{T}$. The parameter estimate for Temp $p_{\text {cow }}$ was positive, indicating that as the external cow surface temperatures increase then so does $\Delta \mathrm{T}$. The $95 \%$ confidence intervals for these four parameter estimates all overlap zero and indicate that $\mathrm{Temp} \mathrm{pmb}_{\mathrm{ar}}, \operatorname{Rad}_{\mathrm{LW}}$, Albedo, and Temp cow regulate $\Delta \mathrm{T}$ and are informative explanatory variables (Table 6).

Table 5. Weather, radiation, and cow albedo models assessed for the difference $(\Delta \mathrm{T})$ between external surface temperatures of cattle (Temp $\left.\mathrm{p}_{\mathrm{cow}}\right)$ and the ambient temperature of the surrounding environment (Temp $\mathrm{pmb}_{\mathrm{a}}$ ) for white, red, and black Bos taurus cows near Laramie, WY, USA.

\begin{tabular}{|c|c|c|c|c|}
\hline Model & $\mathbf{K}$ & AICc & Delta AICc & Weight \\
\hline \multicolumn{5}{|c|}{ Step 1-Weather Models } \\
\hline Ambient Temperature (Temp $\left.p_{a m b}\right)$ & 3 & 4967.08 & 0.00 & 1 \\
\hline Dewpoint Temperature $\left(\right.$ Temp $\left._{\mathrm{dew}}\right)$ & 3 & 5184.00 & 216.92 & 0 \\
\hline Wind Speed & 3 & 5540.83 & 573.75 & 0 \\
\hline Null & 2 & 5684.51 & 717.43 & 0 \\
\hline \multicolumn{5}{|c|}{ Step 2-Radiation Models } \\
\hline Long-wave Radiation $\left(\operatorname{Rad}_{\mathrm{LW}}\right)$ & 3 & 5142.32 & 0.00 & 1 \\
\hline Short-wave Radiation (Rad $\left.{ }_{S W}\right)$ & 3 & 5258.25 & 115.93 & 0 \\
\hline Clear Sky Insolation (KTClear) & 3 & 5616.83 & 474.51 & 0 \\
\hline Null & 2 & 5684.51 & 542.19 & 0 \\
\hline \multicolumn{5}{|c|}{ Step 3-Top Models + Animal Attributes [Winter Albedo and Temp cow $_{\text {- }}$ ] } \\
\hline $\begin{array}{c}\text { Tempamb }+\operatorname{Rad}_{\mathrm{LW}}+\text { Albedo }+ \\
\text { Temp }_{\text {cow }}\end{array}$ & 6 & $-38,308.95$ & 0.00 & 1 \\
\hline $\mathrm{Temp}_{\mathrm{amb}}+\operatorname{Rad}_{\mathrm{LW}}+\mathrm{Temp}_{\mathrm{cow}}$ & 5 & $-38,197.42$ & 111.53 & 0 \\
\hline $\mathrm{Temp}_{\mathrm{amb}}+\operatorname{Rad}_{\mathrm{LW}}+$ Albedo & 5 & 4674.41 & $42,983.36$ & 0 \\
\hline $\mathrm{Temp}_{\mathrm{amb}}+\operatorname{Rad}_{\mathrm{LW}}$ & 4 & 4961.41 & $43,270.42$ & 0 \\
\hline $\mathrm{Rad}_{\mathrm{LW}}$ & 3 & 5142.32 & $43,451.27$ & 0 \\
\hline Temp $p_{\mathrm{amb}}$ & 3 & 4967.08 & $43,276.03$ & 0 \\
\hline Null & 2 & 5684.51 & $43,993.46$ & 0 \\
\hline
\end{tabular}

Table 6. Top candidate model parameter estimates and 95\% confidence intervals for the difference $(\Delta \mathrm{T})$ between external surface temperatures of cattle $\left(\mathrm{Temp}_{\mathrm{cow}}\right)$ and the ambient temperature of the surrounding environment (Temp $\mathrm{amb}_{\mathrm{a}}$ ) for white, red, and black Bos taurus cows near Laramie, WY, USA.

\begin{tabular}{cccc}
\hline Variable & Estimate & Lower & Upper \\
\hline Ambient Temperature $\left(\mathrm{Temp}_{\mathrm{amb}}\right)$ & -0.8230 & -0.8672 & -0.7787 \\
Long-wave radiation $\left(\mathrm{Rad}_{\mathrm{LW}}\right)$ & -8.3971 & -8.9595 & -7.8347 \\
Albedo & -24.160 & -29.8022 & -18.5184 \\
Cow Surface Temperature $\left(\mathrm{Temp}_{\mathrm{cow}}\right)$ & 0.5022 & 0.37772 & 0.62661 \\
\hline
\end{tabular}

Temp amb was highly corelated (all $r^{2}$ values $>0.7$ ) and a significant predictor of $\Delta \mathrm{T}$ for all cow hide colors (all $p$-values $<0.0001$ ) (Figure 5). The slopes $(\mathrm{m})$ of the relationships were also significantly different according to ANCOVA and Kruskal-Wallis post hoc comparisons (all $p$-values $<0.001$ ) suggesting different $\Delta \mathrm{T}$ responses; for example, for white cows $\mathrm{m}=-0.45$, for red cows $\mathrm{m}=-0.92$, and for black cows $\mathrm{m}=-1.07$, which indicate this relationship is $\sim 2 \times$ stronger for red and black cows than for white cows. In addition, the negative $\mathrm{m}$ values indicate that $\Delta \mathrm{T}$ decreases as temperatures increase (Figure 5). 

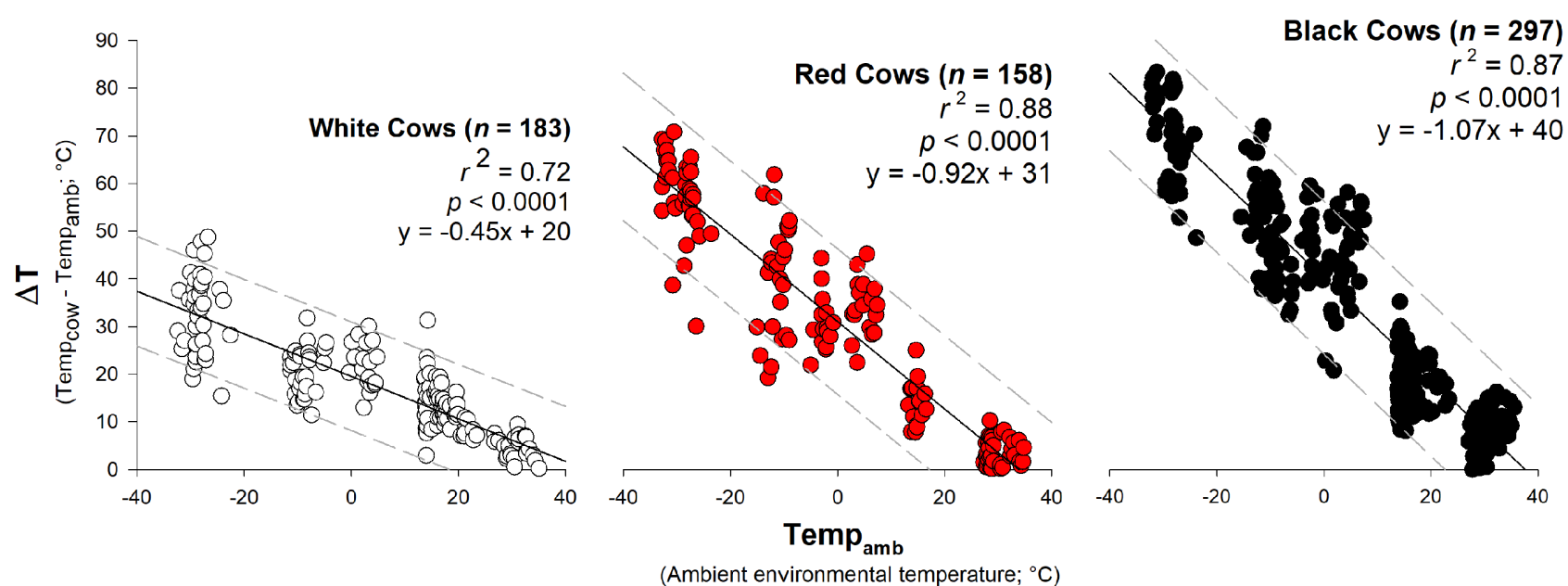

Figure 5. Linear least-squares regression to analyze how ambient environmental temperature (Temp amb) predicts $\Delta \mathrm{T}$ (the difference between cattle surface temperature (Temp $\left.p_{c o w}\right)$ and Temp $p_{a m b}$ ) stratified by cow hide color for white, red, and black cows. Strength of relationships was determined based on the correlation coefficient $\left(r^{2}\right)$ and significant statistical differences based on $\alpha=0.05$. Cattle were red, white, and black Bos taurus cows free roaming on rangeland west of Laramie, WY, USA at the University of Wyoming, Agriculture Experiment Station, Laramie Research and Extension Center-Beef Unit. Dashed lines represent $95 \%$ prediction bands.

\section{Discussion}

This experiment has established unique winter albedo reference values concomitantly for white, red, and black Bos taurus cows for the first time in the published literature [11]. These reference values are important for examining the thermal ecology of phenotypically diverse cattle, particularly in the context of the external surface temperatures of cows relative to solar radiation drivers in both the infrared and visible spectrums [9]. The variation of winter albedo values within a single hide color in this study suggests that assessment of genotypic-driven stress tolerance should include interactions with phenotypic-driven variation in albedo, even within a uniform colored group of cattle [43]. Moreover, in many production environments, including the environment of this study, the landscape is very open with little to no shade available to cattle [16]. An important caveat to this study is the albedo values were derived during the middle of winter when pixel brightness of digital images could be relativized to snow in the image-a scenario that is not possible in the summer. This context must be emphasized because during the winter, cows have hair coats that tend to be thicker and rougher than the thinner and sleeker coat of the summer. This is important because evidence suggests that the summer coat may have a higher albedo value which can help decrease the solar heat load [44].

Looking to the future, the preference for black hided cattle and subsequent increase in such cattle in the US and other regions [13,14], coupled with climatic change that includes increasing temperatures [1], should lead to more focus on these interactions. For example, these results suggest that black cattle may suffer more thermal stress ("heat stress") in the summer while white cattle may suffer more thermal stress ("cold stress") in the winter. Furthermore, this may also suggest that such contrasting advantages and disadvantages may have implications for selecting black cattle for colder high-altitude and high-latitude environments and white cattle for warmer tropical environments, particularly considering the climate extremes on opposite ends of the thermal gradient in such contrasting environments. Moreover, understanding the variation of performance of heterogeneous groups of cows [45] or growing cattle such as yearling steers or heifers [46,47], in harsh environments, may be enhanced by understanding cow albedo and thermal ecology. Ultimately, the understanding of solar radiation $\times$ hide color interactions has implications for optimizing cattle selection and breeding for thermoregulatory advantages in different environments. 
The differential role of various solar metrics for predicting Temp $\mathrm{p}_{\text {cow }}$ versus $\Delta \mathrm{T}$ also provides greater insight for how cattle actually experience temperature [8]. While ambient temperature is relevant for applied livestock management questions or ecological insights, it is the combination of ambient temperature, radiation, albedo, and heat transfer that collectively influence operative temperature [48]. Operative temperature is considered to be the "thermal stress placed on an organism with specified external properties" [49]. Thus, scientists should therefore move beyond only measuring external and internal animal temperatures and propel forward to relating those temperatures to ambient temperatures relative to the external properties of the animal with the understanding that certain radiation metrics are more influential than others. In this study, the role of long-wave radiation was most informative for $\Delta \mathrm{T}$, likely due to how visible short-wave radiation penetrates into the coat but how infrared long-wave radiation is absorbed at the surface of the coat [34].

The variable winter albedo and $\Delta \mathrm{T}$ values relative to different cow hide color groups may also have implications for cold stress which can have negative consequences for animal production [6]. As temperatures drop and cold stress escalates, animals move out of the zone of thermoneutrality as they pass lower critical temperature and enter a cold thermogenesis stage where cold stress manifests and animals alter metabolic rate to generate heat and cope with the cold [5]. At the coldest temperatures, cows with the highest albedo values (white cows) had the lowest $\Delta \mathrm{T}$ values, whereas cows with the lowest albedo values (black cows) had the highest $\Delta \mathrm{T}$ values-values that were nearly $2 \times$ higher. Future research needs to further assess if such an effect translates into different metabolic rates and energy requirements. Based on the role of $\Delta \mathrm{T}$ in the calculation of forced convection which is heat transfer between an organism and its environment [8], logic suggests that black cattle would have greater forced convection rates than white cattle. Additional measurements to understand variation of boundary layer depth and density (i.e., animal hair depth and density) and subsequent interactions with wind speed and Temp amb will also help to enhance the understanding of heat transfer of cattle. Moreover, additional data on the relative clearness or cloudiness of a region and the confounding factor of cloud cover should also be integrated into future studies [28].

The minimal role of wind speed for predicting either Temp $\mathrm{p}_{\text {cow }}$ or $\Delta \mathrm{T}$ in this study is also notable because wind speed is known to be critically important in surface temperature change as it compresses and reduces the animal boundary layer as it increases [36]. In other words, the convection coefficient is known to be inversely related to the boundary layer thickness (i.e., animal hair depth) which is compressed as wind speed increases [36]. More specifically, the calculation of the surface heat transfer coefficient $\left(\mathrm{h}_{\mathrm{c}}\right)$ includes wind speed [8]. The results reported herein, in this context of wind speed, indicate that at the scales measured, and in the context of other variables, wind speed was not as important for predicting either animal temperature response variable, as other solar, temperature, or albedo variables-particularly across the broad cold to hot gradient assessed.

\section{Conclusions}

Quantifying albedo of commingled cattle of different hide colors is basic scientific progress for applied livestock research. As genetic selection for certain genotypes and phenotypes oscillates through time, some phenotypes become more abundant such as the current trend for black hided cattle in the US $[13,14]$. Such industry trends, when coupled with climatic trends, facilitate thermal ecological interactions between animals and their environment that have implications for animal welfare and animal production. For example, there may be thermoregulatory advantages for cows of different color hide colors in different seasons or different regions due to solar radiation $\times$ hide color interactionsblack or red hide cattle in cold periods or cold regions and white hide cattle in warm periods or warm regions. Globally though, there are latitudinal geographic zones that differ in solar energy and thermal stress and the temperate zones of both hemispheres are places where cattle may experience both cold stress in the winter and heat stress in the summer. Understanding how external coat characteristics of animals influence how they experience 
temperature, particularly when temperatures drop below the zone of thermoneutrality and animals enter cold thermogenesis [5], is essential to developing novel strategies for cold stress mitigation in these temperate zones of the world. While such information has application for domestic beef cattle, it also leads to the need to better understand the evolutionary adaptations of wild animals such as American bison (Bison bison) which span broad thermal gradients and are dark colored, and polar bears (Ursus maritimus) which occur in very open and cold environments and are white. In addition to quantifying cow albedo, the understanding that different satellite-derived clearness and radiation metrics have differential influences on variable thermal metrics of cattle is important to guide researchers to measure the most appropriate drivers of thermal stress [34].

Funding: This research was funded by the University of Wyoming through a USDA National Institute of Food (NIFA) and Agriculture McIntire Stennis Project (Animal-plant interaction ecology on Wyoming Rangelands [2015-2020, Project\# WYO-559-15]) and the NIFA Crop Protection and Pest Management (CPPM) and Extension Implementation Program (EIP) (Award\# 2017-70006-27281).

Institutional Review Board Statement: Cattle management followed the guidelines stated in the Guide for the Care and Use of Agricultural Animals in Research and Training [17] and methods were approved by the University of Wyoming-Institutional Animal Care and Use Committee (IACUC) under Protocol \#20170508DS0060-01.

Data Availability Statement: Data can be made available upon request.

Acknowledgments: Appreciation is extended to the staff at the University of Wyoming-Agricultural Experiment Station, Laramie Research and Extension Center.

Conflicts of Interest: The author declares no conflict of interest.

\section{References}

1. Buzan, J.R.; Huber, M. Moist heat stress on a hotter Earth. Annu. Rev. Earth Planet. Sci. 2020, 48, 623-655. [CrossRef]

2. Brown-Brandl, T.M.; Nienaber, J.A.; Eigenberg, R.A.; Mader, T.L.; Morrow, J.L.; Dailey, J.W. Comparison of heat tolerance of feedlot heifers of different breeds. Livest. Sci. 2006, 105, 19-26. [CrossRef]

3. Nienaber, J.A.; Hahn, G.L. Livestock production system management responses to thermal challenges. Int. J. Biometeorol. 2007, 52, 149-157. [CrossRef]

4. Young, B.A. Cold stress as it affects animal production. J. Anim. Sci. 1981, 52, 154-163. [CrossRef] [PubMed]

5. Young, B.A. Ruminant cold stress: Effect on production. J. Anim. Sci. 1983, 57, 1601-1607. [CrossRef]

6. Lister, E.E.; Jordan, W.A.; Wavthy, J.M.; Comeau, J.E.; Pigden, W.J. Effects of housing and type of forage on the response of pregnant beef cows to dietary energy intake in winter. Can. J. Anim. Sci. 1972, 52, 671-679. [CrossRef]

7. Robinson, J.B.; Ames, D.R.; Milliken, G.A. Heat production of cattle acclimated to cold, thermoneutrality and heat when exposed to thermoneutrality and heat stress. J. Anim. Sci. 1986, 62, 1434-1440. [CrossRef]

8. Clarke, A. Principles of Thermal Ecology: Temperature, Energy, and Life; Oxford University Press: Oxford, UK, 2017. [CrossRef]

9. Da Silva, R.G.; Maia, A.S.C.; de Macedo Costa, L.L. Index of thermal stress for cows (ITSC) under high solar radiation in tropical environments. Int. J. Biometeorol. 2015, 59, 551-559. [CrossRef]

10. Gates, D.M. Radiant Energy, Its Receipt and Disposal. In Agricultural Meteorology; Meteorological Monographs Book Series; American Meteorological Society: Boston, MA, USA, 1965; Volume 6. [CrossRef]

11. Perkins, S. Core Concept: Albedo is a simple concept that plays complicated roles in climate and astronomy. Proc. Natl. Acad. Sci. USA 2019, 116, 25369-25371. [CrossRef]

12. Scasta, J.D.; Lalman, D.L.; Henderson, L. Drought mitigation for grazing operations: Matching the animal to the environment. Rangelands 2016, 38, 204-210. [CrossRef]

13. Reiman, M. Nearly 75\% of U.S. Cattle are Black-Hided; a Look behind the Numbers. 2012 Beef Magazine. Available online: https:/ / www.beefmagazine.com/allied-industry/nearly-75-us-cattle-are-black-hided-look-behind-numbers (accessed on 21 February 2021).

14. Rutherford, B. US beef herd is mostly black but changing slightly. 2014 Beef Magazine. 21 February 2021. Available online: https: / / www.beefmagazine.com/cattle-genetics/us-beef-herd-mostly-black-changing-slightly (accessed on 21 February 2021).

15. Peel, M.C.; Finlayson, B.L.; McMahon, T.A. Updated world map of the Köppen-Geiger climate classification. Hydrol. Earth Syst. Sci. 2007, 4, 439-473. [CrossRef]

16. Veissier, I.; Palme, R.; Moons, C.P.; Ampe, B.; Sonck, B.; Andanson, S.; Tuyttens, F.A. Heat stress in cows at pasture and benefit of shade in a temperate climate region. Int. J. Biometeorol. 2018, 62, 585-595. [CrossRef] [PubMed]

17. FASS. Guide for the Care and Use of Agricultural Animals in Research and Teaching; Federation of Animal Science Societies (FASS): Champaign, IL, USA, 2010. 
18. Schneider, C.A.; Rasband, W.S.; Eliceiri, K.W. NIH Image to ImageJ: 25 years of image analysis. Nat. Methods $2012,9,671-675$. [CrossRef] [PubMed]

19. Grenfell, T.C.; Maykut, G.A. The optical properties of ice and snow in the Arctic Basin. J. Glaciol. 1977, 18, 445-463. [CrossRef]

20. Hartig, S.M. Basic image analysis and manipulation in ImageJ. Curr. Protoc. Mol. Biol. 2013, 102, 14-15. [CrossRef]

21. Abràmoff, M.D.; Magalhães, P.J.; Ram, S.J. Image processing with ImageJ. Biophotonics Int. 2004, 11, 36-42.

22. Keski-Korsu, M. How to Calculate Albedo Yourself? Arts Promotion Centre Finland, Taiteen Edistämiskeskus. Available online: http:/ / albedodreams.info/how_to/how-to-calculate-albedo-yourself/\#: \{\}:text=The\%20albedo\%20is\%20calculated\% 20as, white\%20paper $\backslash \mathrm{T} 1 \backslash$ textquoterights\%20known\%20albedo\%20value (accessed on 21 February 2021).

23. Lees, A.M.; Salvin, H.E.; Colditz, I.; Lee, C. The influence of temperament on body temperature response to handling in Angus cattle. Animals 2020, 10, 172. [CrossRef]

24. Daly, C.; Halbleib, M.; Smith, J.I.; Gibson, W.P.; Doggett, M.K.; Taylor, G.H.; Curtis, J.; Pasteris, P.P. Physiographically sensitive mapping of climatological temperature and precipitation across the conterminous United States. Int. J. Climatol. 2008, 28, 2031-2064. [CrossRef]

25. PRISM Climate Group. Oregon State University. Available online: http:/ / prism.oregonstate.edu (accessed on 21 February 2021).

26. NASA. Prediction of Worldwide Energy Resources. National Aeronautics and Space Administration. Available online: https: / / power.larc.nasa.gov / (accessed on 21 February 2021).

27. Mount, L.E. Heat transfer between animal and environment. Proc. Nutr. Soc. 1978, 37, 21-27. [CrossRef]

28. Mathiesen, P.; Kleissl, J. Evaluation of numerical weather prediction for intra-day solar forecasting in the United States. Sol. Energy 2011, 85, 967-977. [CrossRef]

29. Diéguez, A.P.; Gentile, N.; von Wachenfelt, H.; Duboisb, M. Daylight utilization with light pipe in farm animal production: A simulation approach. J. Daylighting 2016, 3, 1-11. [CrossRef]

30. Cossins, A. Temperature Biology of Animals; Springer: Berlin, Germany, 2012.

31. Fuquay, J.W. Heat stress as it affects animal production. J. Anim. Sci. 1981, 52, 164-174. [CrossRef]

32. Still, C.J.; Pau, S.; Edwards, E.J. Land surface skin temperature captures thermal environments of C3 and C4 grasses. Glob. Ecol. Biogeogr. 2014, 23, 286-296. [CrossRef]

33. Dikmen, S.; Hansen, P.J. Is the temperature-humidity index the best indicator of heat stress in lactating dairy cows in a subtropical environment? J. Dairy Sci. 2009, 92, 109-116. [CrossRef] [PubMed]

34. Walsberg, G.E.; Campbell, G.S.; King, J.R. Animal coat color and radiative heat gain: A re-evaluation. J. Comp. Physiol. 1978, 126, 211-222. [CrossRef]

35. Guthrey, F.S.; Rybak, A.R.; Fuhlendorf, S.D.; Hiller, T.L.; Smith, S.G.; Puckett, W.H., Jr.; Baker, R.A. Aspects of thermal ecology of bobwhites in north Texas. Wildl. Monogr. 2005, 159, 1-36. [CrossRef]

36. Porter, W.P.; Gates, D.M. Thermodynamic equilibria of animals with environment. Ecol. Monogr. 1969, 39, 227-244. [CrossRef]

37. Edwards, R.M.; Haines, H. Effects of ambient water vapor pressure and temperature on evaporative water loss in Peromyscus maniculatus and Mus musculus. J. Comp. Physiol. 1978, 128, 177-184. [CrossRef]

38. Mazerolle, M.J. AICcmodavg: Model Selection and Multimodel Inference Based on (Q)AIC(c). Available online: https:/ / cran.rproject.org/web/packages/AICcmodavg/index.html (accessed on 21 February 2021).

39. R Core Team. R: A Language and Environment for Statistical Computing; R Foundation for Statistical Computing: Vienna, Austria; Available online: https:/ / www.r-project.org/ (accessed on 21 February 2021).

40. Coppedge, B.R.; Fuhlendorf, S.D.; Harrell, W.C.; Engle, D.M. Avian community response to vegetation and structural features in grasslands managed with fire and grazing. Biol. Conserv. 2008, 141, 1196-1203. [CrossRef]

41. Kaszta, Ż.; Marino, J.; Wolff, E. Fine-scale spatial and seasonal rangeland use by cattle in a foot-and-mouth disease control zones. Agric. Ecosyst. Environ. 2017, 239, 161-172. [CrossRef]

42. Burnham, K.P.; Anderson, D.R. A Practical Information-Theoretic Approach: Model Selection and Multimodel Inference; Springer: New York, NY, USA, 2002.

43. Toghiani, S.; Hay, E.; Fragomeni, B.; Rekaya, R.; Roberts, A.J. Genotype by environment interaction in response to cold stress in a composite beef cattle breed. Animal 2020, 14, 1576-1587. [CrossRef] [PubMed]

44. Oke, T.R. Boundary Layer Climates; Taylor \& Francis Group: Abingdon, UK, 1987.

45. Scasta, J.D.; Smith, T. Commingled black and white cows (Bos taurus; Angus and Charolais) in high-elevation rangeland are differentially parasitised by Haematobia irritans. Anim. Prod. Sci. 2019, 59, 1727-1738. [CrossRef]

46. Boyd, B.M.; Shackelford, S.D.; Hales, K.E.; Brown-Brandl, T.M.; Bremer, M.L.; Spangler, M.L.; Wheeler, T.L.; King, D.A.; Erickson, G.E. Effects of shade and feeding zilpaterol hydrochloride to finishing steers on performance, carcass quality, heat stress, mobility, and body temperature. J. Anim. Sci. 2015, 93, 5801-5811. [CrossRef] [PubMed]

47. Kononoff, P.J.; Defoor, P.J.; Engler, M.J.; Swingle, R.S.; James, S.T.; Deobald, H.M.; Deobald, J.L.; Woronuk, G.N.; Marquess, F.L.S. Performance and carcass characteristics when sorting feedlot cattle on the basis of phenotype, and leptin genotype along with differential use of $\beta$-adrenergic agonists. Can. J. Anim. Sci. 2015, 95, 455-463. [CrossRef]

48. Elmore, R.D.; Carroll, J.M.; Tanner, E.P.; Hovick, T.J.; Grisham, B.A.; Fuhlendorf, S.D.; Windels, S.K. Implications of the thermal environment for terrestrial wildlife management. Wildl. Soc. Bull. 2017, 41, 183-193. [CrossRef]

49. Bakken, G.S.; Angilletta, M.J., Jr. How to avoid errors when quantifying thermal environments. Funct. Ecol. 2014, $28,96-107$. [CrossRef] 